\title{
Paleotemperature Changes in the Upper and Middle Pleistocene
}

\author{
By Tomislav ŠEgota, Zagreb
}

With 3 figures.

A bstract. By the combination of land and sea data the author came to the conclusion that the duration of the Middle and Upper Pleistocene glacial ages was of the same order of magnitude. The temperature of the glacial ages was not exactly the same, but each younger glacial age was a little colder than the preceding one. Similarly, each younger interglacial age was a little cooler than the preceding one. Bringing together all known data the complex Pleistocene generalized paleotemperature curve is constructed showing the main trend of the temperature evolution from Mindel glacial until now, spanning the time of about 400,000 years.

$\mathrm{Zusammenfassung.} \mathrm{Aus} \mathrm{festländischen} \mathrm{und} \mathrm{marinen} \mathrm{Daten} \mathrm{wird} \mathrm{gefolgert,} \mathrm{daß} \mathrm{die}$ Glazialzeiten des mittleren und oberen Pleistozäns zeitlich von gleicher Größenordnung waren. Die Temperaturen der einzelnen Eiszeiten waren nicht genau gleich: jede jüngere Eiszeit war ein wenig kälter als die vorhergehende; das gleiche gilt für die Interglaziale. Mit allen bekannten Daten wird eine generalisierte Paläotemperatur-Kurve konstruiert, welche den Trend der Temperatur-Entwicklung vom Mindel bis heute (ca. 400000 Jahre) zeigt.

\section{Introduction}

The radiometric measurement of time revolutionized paleoclimatological investigations, but different competent researchers arrived at chronologies differing by a factor of 5 , and the interpretation of paleoclimatic changes remains a very difficult problem. Paleoclimatic investigation abounds with fundamentally different results and nearly all interpretations can be proved by most recently published data. In this article the present author attempts to bring into accordance with some facts so far known his concepts (ŠEGOTA, 1963) about the general course of the Quaternary paleotemperature changes plotted against the hypothetical chronology inferred by the same author (ŠEGOTA, 1961).

\section{Absolute Chronology of the Paleotemperature Changes}

Due to many radiocarbon and other radiometric measurements the duration of the Würm glacial (60,000 years) is relatively firmly established. In certain degree this can be said even for the Riss-Würm interglacial (40,000 years). The duration of the Riss glacial at this moment is the most important problem of the Pleistocene chronology, because the extrapolations and radiometric measurements in this part of the Pleistocene differ considerably. Such a difficult problem can be solved only by combining all data from the land and the sea. The drift sheets of the older glacial ages in North America and Europe have southern borders similar to that of the latest drift. Such similarity implies that the ice sheets of the different glacial ages formed and spread under essentially the same controls as those which determined the form of the latest ice sheets (FLINT, 1957). It seems probable that the physical conditions were repeated with each glaciation, and that the ice sheets were governed by the same physical and climatic controls (Charlesworth, 1957). Accordingly, our assumption and calculation that the duration of the Riss glacial was of the same order of magnitude as the duration of the Würm glacial is soundly based. This is the basis for the construction of a deep-sea paleoclimatic chronology which fundamentally differs from that given by EMILIANI and his coworkers.

All deep-sea chronologies are based on the sedimentation rates. In this case our hypothetical chronology is founded on the established fact that the sedimentation rates have been considerably greater in glacial than in interglacial ages (BROECKER et. al., 1958). 
The thickness of glacial and interglacial sediments respectively must be in a certain relationship with the temperatures and the duration of them. The durations and the temperatures of all glacial and interglacial ages was not the same and this is the reason why the extrapolations based on "average" or "constant" Pleistocene sedimentation rates cannot be valid. This is exactly the same as was proved on the land we quoted above: similar climatic oscillations must have been accompanied by similar thicknesses of sediments on the sea bottom. More precisely, the thickness of deep-sea sediments precipitated during the Riss glacial must be similar to (not the same as) the thickness of the sediments of the Würm glacial.

According to BROECKER and others (1958) the variation in rate of the coarse fraction $(>74 \mu)$ deposition with the surface ocean temperature is much less than that of the fine fraction. So we shall compare the sedimentation of the carbonate fraction smaller than $74 \mu$ in the core A 179-4 (Rosholt et al., 1961, fig. 7). A certain difficulty arises from the fact that the sedimentation rate was not calculated for separate time-climatic sections (with the exception of the Holocene), and so the upper part of the core section belonging to the Riss-Würm interglacial (Emiliani's stage 5) was added to the stage 6 belonging to Riss). In spite of this, the section belonging to the stage 6 clearly indicates a high glacial rate of sedimentation. Much more important than this is the fact that the rate of the sedimentation between 305 and $450 \mathrm{~cm}$. is exactly the same as that preceding stage 6 . This means that all sections between about 255 (the boundary between Riss glacial and Riss-Würm interglacial) and $450 \mathrm{~cm}$. were deposited under the same cold, we suppose, glacial conditions. The author calculated (1961) that the Riss glacial lasted 20 per cent longer than the Würm glacial. This means that the deep-sea sediments deposited during the Riss glacial must have been about 20 per cent thicker than the Würm sediments (if the sedimentation was not interrupted), i. e. not only the stage 6 , but even the stages 7, 8, 9, and ma; be even the stage 10, belong to the Riss glacial. In accordance with this assumption is the curve representing the weight percentages of the carbonate fraction larger than $62 \mu$ ir the core A240-M1 (Rosholt et al., 1961, fig. 1). The section of the core between 270 an ${ }^{\prime} 610 \mathrm{~cm}$. shows weight percentages much lower than in the part belonging to the Riss-Würm interglacial, but they are very similar to that belonging to the Würm glacial. Just the same can be seen in fig. 2 of Rosholt and others (1961). The curve B representing weight percentages of carbonate fraction smaller than $74 \mu$ clearly is divided in two parts, one belonging to the Würm and Riss glacials with small weight percentages, and another part with great weight percentages belonging to the Riss-Würm interglacial.

Our assumption excellently agrees with $\mathrm{Pa}^{231} / \mathrm{Th}^{230}$ dating of core A240-M1 (RoSHoLt et al., 1961, fig. 1). The remarkable temperature drop at about $530-570 \mathrm{~cm}$., or between 148,000 and 175,000 years B.P., clearly shows that this drop of temperature represents the first temperature drop of the Riss glacial, it represents its first stadial.

EMILIANI and his coworkers founded their absolute time scale on the assumption that the bulk rate of sedimentation remained approximately constant. If we suppose - as in the previous case - that the sedimentation rate during the Mindel-Riss interglacial was of the same order of magnitude as in other interglacial ages, the thickness of the sediments deposited during this interglacial age must have been the function of its duration, and more than this the function of the temperature. However, the duration of the MindelRiss interglacial was much greater than the duration of the last interglacial age, and the temperature was higher (the effect was the lower sedimentation rate) than in the RissWürm interglacial. We suppose that the stages 11, 12, and 13 (EMILIANI 1955a; 1958; 1961 ; 1964) represent the great interglacial age. The temperature drop within the great interglacial age (stage 12) represents a wellknown cooling of the climate a little time after the middle of this interglacial age. Stage 14 would represent a maximum of the 


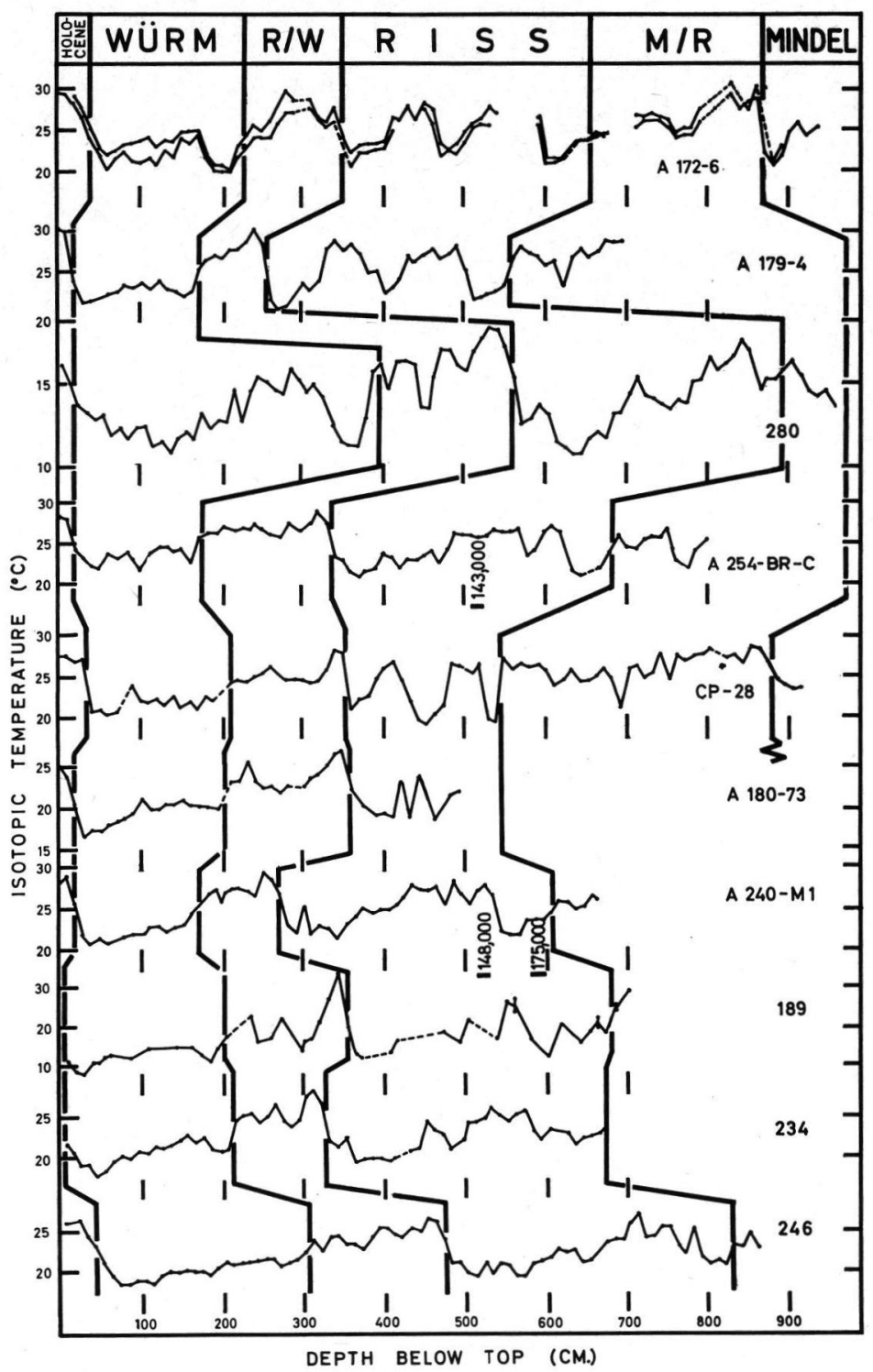

Fig. 1. Paleotemperature curves of ten deep-sea cores from the Atlantic Ocean and the Mediterranean Sea. Core numbers to the right. Tentative correlation with terrestrial stratigraphy of the Alps region is suggested above the curve.

Mindel glacial, and the stages 15, 16 and the greater part of the stage 17 (EmilianI, 1964 ; 1966) would belong to the other parts of the Mindel glacial. Thus the thickness of the sediments and the duration of the Mindel glacial would be in a reasonable proportion to the other glacial ages.

The above conclusions well agree with the data derived from the Pacific Ocean. The $27.5 \mathrm{~m}$. long deep-sea core from the Okhotsk Sea can be divided in 5 parts (ZHUZE \& Koreneva, 1959). The thickness of the sediments belonging to the last glacial age is 
$405 \mathrm{~cm}$., and that belonging to the penultimate glacial age is $615 \mathrm{~cm}$. Assuming a similar sedimentation rate during the glacial ages this leads to the conclusion that the duration of the Riss glacial must have been longer than the duration of the Würm glacial. Similarly, the thickness of the sediments belonging to the younger interglacial age is $460 \mathrm{~cm}$., and that of the older interglacial age is $945 \mathrm{~cm}$.

At last, our chronology is based on a simple comparison between various paleotemperature curves which in essence is very similar to Olausson's (1965) chronology. We have no problems with the Würm glacial and Riss-Würmr interglacial, the difficulties arise deeper in the past. The comparative analysis of the paleotemperature curves (fig. 1) reveals that the oxygen isotope method, quite naturally, now is not an absolutely safe technique for the calculation of paleotemperature changes. The best example is EmILIANI's Würm I, which is very clearly discernible in the cores A 172-6, A 179-4, 280, and A 254BR-C (Rosholt et al., 1962); this minimum (stage 4) was as low as the minimum of the stage 2 (Würm maximum). The cores 234, 189 and A 180-73 show slightly higher temperatures during Würm I which cannot compare with the drop of the temperature in previous cores. No temperature drop at all, or a hardly perceptible drop, can be revealed in the same stage of the cores 246, A 240-M1 and CP-28. In spite of this marked difference the extreme evidence of the cores A 179-4 and A 172-6 outweighed the evidence of the other cores raised later and the first paleotemperature curve (EMILIANI, 1955a) at this stage failed to bring into accordance the evidence derived by the study of the cores raised later (Emiliani, 1958, 1961, 1964, 1966; Rosholt et al., 1961).

Similarly, the temperature oscillations corresponding to Emiliani's stages 6, 7, 8, 9 and 10 , or to the Riss glacial according to our chronology, are not the same in all curves and thus can be interpreted in another way than did EmILIANI and his coworkers. Cores A 179-4 and A 172-6 are the representatives of the extreme group with very pronounced amplitudes (not so pronounced in some cores raised later). Contrary to this, the cores 234, 189, A 254-BR-C, and especially the core 246, are in this part very similar to the "cold wave" representing the Würm glacial, indicating that this part of the curve belongs to a long period of time mainly with low temperatures interrupted by warmer episodes. The marked temperature drop at the beginning of the Riss glacial (stage 10, or Mindel glacial in Emiliani's curves) probably was not so pronounced. This is the result of the analysis of the earlier cores A 172-6 and A 179-4, and confirmed by the cores A 240-M1, A $254-B R-C$ and 189. This is very similar to the exaggerated cooling at the beginning of the Würm glacial. The cores 280, 234 and 246 give no evidence for such strong cooling at the beginning of the Riss glacial. These cores show that the first Riss stadial was not as cold as the younger Riss stadials, and this is in good agreement with the similar mechanism confirmed during the Würm glacial. Bearing in mind that the isotopic curves show phases within the Würm glacial there seems to be no reason to correlate the Riss glacial with a single temperature minimum of short duration which cannot be compared with the duration of the Würm glacial (Olausson, 1965).

\section{Thermal Evolution of the Quaternary Period}

Given that the oxygen isotope paleotemperature measurements is not an absolutely precise method on the one side, and the small temperature differences between two successive glacial or interglacial ages (especially in the lower latitudes) on the other side, we shall try to bring the data so far known into accordance with the established facts on the lands. Namely, the generalized paleotemperature curve must be the result of a study of many pertinent data both from the land and the sea. Detailed investigations all over the world revealed that each successive glacial and interglacial was respectively a little colder than the preceding one (ŠEGOTA, 1966) as a continuation of a general coo- 
ling of the Earth since the Eocene time. The Quaternary glaciation was not characterized by the succession of equally cold glacial ages and equally warm interglacial ages. The temperature differences between them were rather small but it is possible to discern them and in all cases it had a certain "practical" meaning (for the distribution of plants and animals, etc.).

\section{The Temperature of the Holocene Warm Period}

The estimated temperatures of the Holocene warm period differ considerably. The mean temperature of the Tapes-Littorina Sea was $1-3^{\circ} \mathrm{C}$. higher than to-day. Northeastern Ireland was warmer than now by about $1.7^{\circ} \mathrm{C}$., Switzerland by $2-3^{\circ} \mathrm{C}$., Bohemia and Central Germany by $2.3-2.6^{\circ} \mathrm{C}$., Denmark by $1.5-2^{\circ} \mathrm{C}$. in the summer months (the detailed review in Charlesworth, 1957, and Deevey \& Flint, 1957). Ložek (1964) assumed $1-2^{\circ} \mathrm{C}$. and even $3^{\circ} \mathrm{C}$. higher temperatures in Czechoslovakia. It seems that the estimate made by FIRBAs (1949), 1.5-2.4 ${ }^{\circ} \mathrm{C}$. higher temperature of the vegetative period than now in Central Europe, is very close to the real values.

A much higher temperature rise $\left(3.2^{\circ} \mathrm{C}\right.$.) was supposed by Richmond (1953) in Utah, USA, and about $2.7^{\circ} \mathrm{C}$. higher temperature than now in southeast Canada (Terasmae, 1961).

As in all glacial and interglacial ages, the temperature difference must have been much greater in middle latitudes than in the lower one. If we assumed about $1.8^{\circ} \mathrm{C}$. higher temperature than now in the middle latitudes, the corresponding rise of the temperature in the equatorial Atlantic and the Caribbean Sea would amount to abrut $1^{\circ}$ or even $1.5^{\circ}$ more than now (EMILIANI, 1955a; 1956).

\section{The Temperature of the Würm Glacial}

The differences in the estimates of the temperature drop during the last glacial age in middle latitudes vary between $3-4^{\circ} \mathrm{C}$. and $10-12^{\circ} \mathrm{C}$. Most recent estimates are very high, not rarely even more than $12^{\circ} \mathrm{C}$. (Poser, 1947: about $15^{\circ} \mathrm{C}$.; Manley, 1951: annual mean for south-east England about $-2^{\circ} \mathrm{C}$.; WeIsChet, 1954: 10-12 ${ }^{\circ} \mathrm{C}$. lower July temperatures and at least $16^{\circ} \mathrm{C}$. lower winter temperatures; EMILIANI, 1955b, 1961: temperature range of about $12^{\circ}$ in the Mediterranean Sea; ProšEK \& LožEK, 1957: 10 Büdel, 1960: $14^{\circ} \mathrm{C}$; Kaiser, 1960: 15-16 C.; Shotton, 1962: $12.5^{\circ} \mathrm{C}$.; Kopp, 1963: $12^{\circ}$ lower mean annual temperature in San Sebastian, Spain; PÉcsi, 1963: mean annual temperature in Hungary was $-2^{\circ}$ to $-3^{\circ} \mathrm{C}$.; PANOv, 1964: $0^{\circ}$ to $-10^{\circ} \mathrm{C}$. mean annual temperature in Central Europe; Markov, 1965: $12^{\circ}$; Williams, 1965: about $-6^{\circ} \mathrm{C}$. mean annual temperature in England.) Similar values are obtained in the USA (BLAcK, 1964: $10-15^{\circ} \mathrm{C}$. lower mean annual temperature than now; Dillon, 1956 : about $13.8^{\circ} \mathrm{C}$. colder at the edge of the ice sheet. The temperature inversion in winter was responsible for such strong cooling (MORTENSEN, 1952). We suppose that the drop of the temperature in Central Europe in the maximum of the Würm glacial was about $12^{\circ} \mathrm{C}$. (FLoHN, 1953: $13^{\circ}$ C.; Woldstedt, 1958a: $12^{\circ}$ C.; Schwarzbach, 1961: 8-13 C.).

The minimum temperature was attained not in the middle of the Würm glacial, but closer to its end. The temperature curve of the Würm glacial - like the temperature curves of all other glacial ages - was not a symmetrical, but an asymmetrical one. The relation between the phase of the areal expansion (about 48,000 years in the case of the Würm glacial) and the phase of the recession (about 12,000 years) is $4: 1$. This relation is always the same, regardless of the duration and the age of the glacial age.

The basis for the reconstruction of the Würm climate was the well-known paleotemperature curves given by Woldstedt (1962), Gross (1964), Flint (1963), and some other authors. However, the curves are corrected in accordance with some results of 
investigation tending to damp the oscillations between successive phases (KRETZOI, 1961; De Ploey, 1961).

The durations of all younger stadials and interstadials are very small in comparison with the duration of the Upper and Middle Pleistocene and for this reason we shall not go deeply into the study and critical evaluation of many details. No need to quote a very great number of radio-carbon dates; we shall quote only the dates which are most suitable for the construction of the curve.

The Younger Dryas period lasted about 800 years between 10,000 and 10,800 years ago. From Alleröd to Younger Dryas the forest line was lowered by $600 \mathrm{~m}$. The temperature in Germany was by $7-8^{\circ} \mathrm{C}$. lower than now (FIRBAs, 1947), in Kent, England, the mean temperature was about $0^{\circ} \mathrm{C}$. (KenNeY et al., 1964), and the mean July temperature in Central Europe was $6^{\circ} \mathrm{C}$. lower than to-day (IVERSEN, 1954). In central Poland the July temperature was $6^{\circ} \mathrm{C}$. lower than now (Wasilikowa, 1964). We assumed a $6^{\circ} \mathrm{C}$. lower mean annual temperature of the Younger Dryas maximum in Central Europe.

A 11 eröd period. This warm period lastet from 10,800-12,000 years ago. The treeline was only $400 \mathrm{~m}$. lower than to-day, and the mean July temperature in Central Europe was about $4^{\circ} \mathrm{C}$. colder than now (Firbas, 1947), $2^{\circ} \mathrm{C}$. colder in middle Poland (Wasilikowa, 1964). In northern Europe the temperature was 2-3 $3^{\circ} \mathrm{C}$. lower than to-day (IvERSEN, 1954). We assumed a $3^{\circ} \mathrm{C}$. lower mean annual temperature than now in Central Europe.

The Older Dryas period lasted from 12,000 to 13,000 years ago. According to Firbas (1949) the tree-line was $1450 \mathrm{~m}$. lower than now. We assumed that the mean annual temperature in Central Europe was $7^{\circ} \mathrm{C}$. lower than now.

The Bölling period began 14,500 years ago and ended 13,000 years ago. In middle Poland the mean July temperature was $3^{\circ} \mathrm{C}$. lower than now, and in Denmark (IVERSEN, 1954) the mean July temperature was a little higher than $10^{\circ} \mathrm{C}$.

The Wü rm maxim um. Recent radiocarbon measurements give no ground to revise this earlier estimate of Würm maximum (20,000-22,000 years ago). Many authors, especially Dubors (1933), concluded that the Würm maximum was the coldest episode of the Quaternary period. By the analysis of the loess fauna BRANDTNER (1956) came to the same conclusion. Similarly, the fauna reveals that the Würm maximum was the coldest phase of the Ukrainian Pleistocene (Pidoplitshoo, 1961).

The paleotemperature curves of six deep-sea cores clearly confirm the above conclusion (fig. 1). The temperature drop at the stage 2 was bigger than in the stage 6 (Riss maximum) in the cores A 180-73, 246, 234, 189, A 240-M1, and CP-28. Even Emiliani (1958) states that most cores indicate that the stage 2 was the coldest episode of the Pleistocene. In spite of such an important conclusion EMILIANI in his well-known paleotemperature curves presented the paleotemperature maxima and minima as having reached the same values repeatedly, implying that the temperatures of the major glacial maxima were the same. Clearly, this is not in accord with his results of investigations.

The climate of the Würm glacial between the maximum and the first really colder Würm stadial (about 46,000-50,000 years ago), now is not clear enough. Numerous C14 dates differ considerably, but in comparison with the data from North America (FuINT, 1963) we assumed that the $\mathrm{Paudorf}$ interstadial (or merely the warm oscillation?) lasted from about 25,000-28,000 years ago. The very controversial Göttweig Interstadial is replaced by the name "Würmian Interpleniglacia l". (Gross, 1964). The climate on the average was cool temperate interrupted by warmer and colder oscillations. The mean July temperature at Fladbury (Worcester) about 38,000 years ago (GRO 1269) was lower by $5.5^{\circ} \mathrm{C}$. (Coope, 1962), or $6^{\circ} \mathrm{C}$. (Coope, 1965) than to-day. 
Special attention must be dedicated to the third Würm stadial (GRO 1219: $48,300 \pm 2,000$ years), or Würm I. There are no firm grounds for believing that Würm I was as cold as the Würm maximum. In the earlier EmILIANI's curves the duration of this stadial was represented at about $60,000-70,000$ years B.P. and in his later curves between 50,000 and 65,000 years ago. Woldstedt (1962) put this stadial at about 50,000 years ago, and Gross (1964) at about 48,000-54,000 years ago. SuEss (1956) concluded that this was only a less pronounced temperature minimum at about 55,000 years ago. Similar temperature evolution was confirmed by the study of periglacial phenomena in Poland (DyLıK, 1964). The climate of the older Würm was cool and relatively humid; very low temperatures were attained later in the Würm maximum. The molluscan fauna in Váh valley in Czechoslovakia confirm that the Würm I had a fairly warm steppe character. It was only in the second half of the Würm that the strong development of the cold-loving boreal and boreoalpine fauna set in (LožEK, 1951). Würm I was less cold than any other Würm stadial (PROŠEK \& LOžEK, 1957). Summarizing the regularity of Würm loess sedimentation in Sachsen, Lieberoth (1964) concluded that the Wa loess belonging to the early Würm is usually thin; W $\beta$ loess referred to as middle Würm is somewhat thicker. W $\gamma$ loess which is assigned to late Würm is very thick. This proves a similar process of progressive climatic cooling with the pronounced minimum in the late Würm.

The same took place in the Llano Estacado (Hafsten, 1964). During Terry Pluvial (contemporaneous with Middle Würm) summer temperatures were probably more than $5^{\circ} \mathrm{C}$. cooler than to-day. But during Tahoka Pluvial (22,500-14,000 years ago) the temperatures both in summer and in winter were probably $8-10^{\circ} \mathrm{C}$. lower than at present.

The Brörup-Loopstedt interstadial was the second Würm stadial. Its duration was put at 50,000-60,000 years B.P. (Coope et al., 1961). At Chelford (England) 57,000 years ago, the mean July temperature was about $2-3^{\circ} \mathrm{C}$. lower than now (Shotтon, 1962). In Czechoslovakia the mean annual temperature was about $6^{\circ} \mathrm{C}$. lower than now (LOŽEK, 1964).

The second W ürm stadial was relatively weak; its duration was estimated at 60,000-62,000 years ago (Coope et al., 1961).

The Amersfoort interstadial was the first Würm interstadial. The radiocarbon date 64,000 $\pm 1,100$ years ago (GRO 1397; HARING at al., 1958) ist believed to refer to this interstadial. The mean annual temperature in Czechoslovakia was about 4-5 ${ }^{\circ}$ C. lower than now (LožEK, 1964).

The first W ürm stadial (70,000-67,000 years ago) initiated the beginning of the Würm glacial.

\section{The Temperature of the Riss-Wuirm-Interglacial}

The Riss-Würm interglacial age lasted, according to our calculation, about 40,000 years. The temperature in the thermal optimum of this interglacial age was not only higher than to-day, but - it is believed by some authors - even higher than in the thermal maximum of Holocene time. In Central Europe flourished plants like Brasenia purpurea, Vitis silvestris, Juglans regia, Aldrovanda vesiculosa, Trapa natans, Naias flexilis, N. marina, Dulichium spathaceum, most of which do not now live in this area. The wellknown investigations made by Jessen \& MiLthers (1928) and the inferred temperatures $2{ }^{\circ} \mathrm{C}$. higher than to-day in Denmark and northwestern Germany were confirmed in almost all parts of the world. Some authors (GAMs, 1954) have assigned to this interglacial age a classical interglacial sequence with Rhododendron ponticum and other species some of which are distinctly southern and do not now live in the Alps. The implied former mean annual temperature was warmer than the present by at least $2^{\circ} \mathrm{C}$. (PENCK \& BRÜCKNER, 1909). 


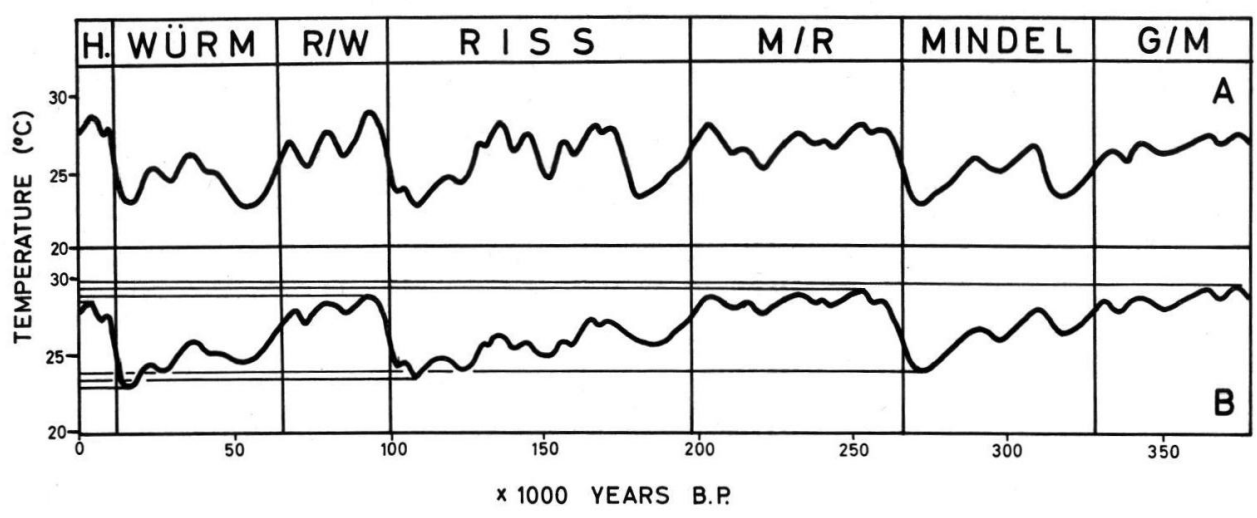

Fig. 2. A possible interpretation of the well-known paleotemperature curve of EmiLIanr. Tentative correlation with the terrestrial stratigraphy of the Alps region suggested by the author is not in accord with Emiliani's absolute chronology. A. Emiliani's paleotemperature curve and time scale (the correlation with the terrestrial stratigraphy is given by the author). B. The amplitude of Emiliani's paleotemperature curve and the general trend of a slight over-all decrease of temperature as brought into accord with terrestrial evidence. The time scale is of EMILIANI.

In the North Sea Basin there lived representatives of the so-called Lusitanian fauna which comprised several species now living in the Mediterranean and off the coasts of Portugal and France (e. g. Tapes aureus var. eemsiensis, Gastrana fragilis, Lucina divaricata, Mytilus lineatus, Haminea navicula, Syndesmya ovata, Turritella communis, Eulimella nitidissima). In the Mediterranean Sea there lived some species which to-day do not live in this sea (GARGALLO, 1962), or - in the majority of cases - now thrive off the Moroccan coast or even in much lower latitudes (e. g. Strombus bubonius, Conus testudinarius, Mytilus senegalensis, Natica lactea, Bittium Deshayesi, Eastonia rugosa). The molluscan fauna in the Netherlands lived in water with temperatures 2 or $3^{\circ} \mathrm{C}$. higher than at present (STRAATEN, 1956). During the last interglacial age there lived in England and Central Europe a pond tortoise Emys orbicularis indicating a mean July temperature $2-3^{\circ} \mathrm{C}$. higher than to-day (UlLRICH, 1956).

To the Riss-Würm interglacial belongs a molluscan fauna from Czechoslovakia (Helicigona banatica, Soosia diodonta, Gastrocopta theeli, Aegopis verticillus, Cepaea nemoralis, Laciniaria stabilis, Pagodulina pagodula, etc.) which lived in a climate $2-3^{\circ} \mathrm{C}$. warmer than now (PROšEK \& LožEK, 1957; Ż́RUBA et al., 1962), or even 2-4º C. warmer than to-day (LožeK \& KUKLA, 1961; LožEK, 1964). The insect fauna from Bobbits Hole, Ipswich, indicate an average July temperature at least $3^{\circ} \mathrm{F}$. warmer than to-day (CoOpE, 1965). The "islands" of fossil chernozem found nowadays in dry localities of Central Europe were steppe islands which developed under a warmer climate than now. From south-west Germany westwards, in France particularly, and also in the Thames valley, the soils of the Riss-Würm interglacial have a colour more reddish than that of ordinary brown-earth. This can only mean that the climate had a tendency towards the Mediterranean climate (Zeuner, 1959). Paleopedological investigations in south-east Europe gave the same results; about $2-3^{\circ} \mathrm{C}$. higher temperatures than now in the last three interglacial ages (JARANOFF, 1944). This was the effect of summers hotter and drier than at present (MARKović-Marjanović, 1964). In the travertines of middle Germany have been found Pinus cf. nigra, Quercus cf. virgiliana; this implies a mean July temperature about $2-3^{\circ} \mathrm{C}$. higher than to-day (VENT, 1958). The fossils of Buxus sempervirens, Juglans regia, Thuja occidentalis and Quercus mammutbi in Bilzingsleben implies (WERTH, 1925) $1.5-2^{\circ} \mathrm{C}$. higher mean annual temperature. According to the displacement of the northern 
boundary of Tilia tomentosa, it was deduced by Rabien (1953) that the mean annual temperature at Wallensen was about $3^{\circ} \mathrm{C}$. higher than now.

One of the best known units ascribed to the Sangamon is the Toronto formation with the Don beds indicating a mean temperature higher than now by $2-3^{\circ} \mathrm{C}$. (WATT, 1954).

The temperature was not uniform, but the temperature oscillations cannot compare with those of the glacial ages. In Denmark the warm phases II and IV are separated by the subarctic phase III. In the last interglacial age one can trace one, or may be two cooler temperature oscillations (ZEUNER, 1959). The temperature oscillations during RissWürm interglacial are confirmed in all deep-sea cores, especially in the core 234 (Emiliani, 1958) which prove the existence of two cool oscillations. Paleopedological investigations in Austria (BRANDTNER, 1956) proved a cool oscillation in the younger half of this interglacial age. Two sea-levels $(18$ and $7.5 \mathrm{~m}$.) are believed to be in connection with the climatic changes (ZEUNER, 1954). Soil profiles in Czechoslovakia indicate a cool oscillation separating two warm periods (VALOCH, 1959).

\section{The Temperature of the Riss Glacial}

The Riss glacial lasted 72,000 years (110,000-182,000 years B.P.). One must suppose that the mechanism of the development of the ice sheets in the northern hemisphere was in essence similar to that in the Würm glacial. The extent of the Rissian ice sheets leads to the conclusion that the temperature drop must have been of the same order of magnitude as that during the Würm glacial. ShotTon (1962) estimated the drop of the temperature in Britain at $9^{\circ} \mathrm{C}$. at least, but he is convinced that it was even greater. The temperature difference between the Riss and Würm maxima was small and discernible only with difficulty.

In the vicinity of Brno (Moravia) Rissian loess profiles are subdivided into a few loess and fossil soils (PELíšEK, 1954). The detailed faunistic analysis revealed that the Rissian loess in Central Europe was accumulated in a climate with strong maritime influence, contrary to the Würmian loess which was accumulated in a markedly continental climate, i. e. the climate of the Riss glacial was somewhat warmer than the climate of the Würm glacial (LožEK, 1951; BRANDTNER, 1956; ProšEK \& LožEK, 1957).

The floristic development in the Netherlands indicates a warmer interstadial separating Pleniglacial A from Pleniglacial B (Florschürz, 1957). Between the Saale maximum and the Warthe stadial a warm interval was discovered, which was named by BRELIE (1955) the "Ohe-interglacial". Three stadials were discovered in the Pacific deep-sea cores (Hough, 1953). In the vicinity of Berlin the boring discovered four ground moraines belonging to the Saale glacial (CEPEK, 1961). The areal distribution of the moraines in Poland confirms the existence of three stadials (RüHLE, 1957). Probably the most detailed microstratigraphic analysis of Rissian accumulation forms was carried on in the vicinity of Halle, Germany (ScHulz, 1962) confirming many periodic advances and retreats of the ice sheet, which in essence were similar to the Würmian pulsations of the Northeuropean Ice Sheet. These pulsations were similar to an older WoldstedT's (1958b) curve representing the oscillations of the Rissian ice front in Germany.

\section{The Temperature of the Mindel-Riss Interglacial}

Due to its very long duration this interglacial age is called the "Great interglacial“. The reason for such long duration of the Mindel-Riss interglacial is given elsewhere (ŠEGOTA, 1963). We may say summarily that the glacial age on the Antarctic Continent about the middle of the great interglacial age had no equivalent in the northern hemisphere. The thermal influence of the Antarctic glacial age plus the influence of the ex- 
panding Greenland ice sheet and the sea ice in the North Polar Sea were represented as a relatively slight temperature drop a little after the middle of the great interglacial age.

High temperature of the great interglacial age was established in one Pacific Ocean core (Hough, 1953). Calcium carbonate abounds much more in the sediments belonging to the great interglacial age than in the Riss-Würm sediments; this is, probably, the result of warmer water in the great interglacial age than in the Riss-Würm interglacial. Several minor fluctuations are indicated by various shades of colour of the sediments.

The changes of the erosion and accumulation intensity during the great interglacial age in the Thames Valley have been ascribed to climatic oscillations; up to five minor cold phases have been recognized (ZeUner, 1959).

The Tertiary relics Tsuga, Zelkova, Pterocarya, Carya, imply a slightly higher temperature in the great interglacial age than in the Riss-Würm interglacial (GAMs, 1954). In some localities are found Buxus sempervirens, Azolla filiculoides, Vitis silvestris, etc. implying high temperatures, at least in certain periods (WoLDSTEDT, 1958 b). The Cannstatt fossil flora is very similar to the recent Colchic flora and this proves that in the climatic optimum of this interglacial the temperature was $2-3^{\circ} \mathrm{C}$. higher than today (BERTSCH, 1927). A fossil flora in the Lublin area with Vitis silvestris implies that the mean annual temperature was at least $2^{\circ} \mathrm{C}$. higher than now (SoBolewsKA, 1954). During the thermal maximum of this interglacial age in Ireland there grow Abies, Picea and Rhododendron, denoting a climate a little warmer than during the warm period of the Holocene (WATTS, 1959). The pollen curves of Pinus and Betula in the pollen diagrams from Central Europe denote a cooler phase in the great interglacial age (WoLDSTEDT, 1954). This was proved by many paleobotanic investigations in Poland (ŚRodoń, 1954).

The high temperature of the Mediterranean Sea water is confirmed by the occurrence of a warm fauna (Gignoux, 1913) with Strombus bubonius, Matbilda canariensis, Tritonium ficoides, Cardita senegalensis, Mytilus senegalensis, Conus guinaicus, Natica lactea and other species with tropical affinities, which to-day find their northern limit off the Senegal coast or are restricted to the warmest part of the Mediterranean Sea. The shells Lutraria rugosa and Pecten polymorphus, the representatives of the warm Tyrrhenian in Britain, no longer thrive north of Madeira and Portugal (Charlesworth, 1957). Of the same age are the Paludina Beds in the Berlin area with thermophile freshwater molluscs Paludina diluviana etc.

In the vicinity of Prague, chernozem strata are separated by a layer of loess which was precipitated under cool conditions belonging to the great interglacial age. The occurrences of Helix pomatia, Fruticicola fruticum, Celtis sp. in Moravia denote a strong influence of the Mediterranean climate (PROšEK \& LOŽEK, 1957) with 3-4 C. higher temperature in the thermal maximum than now (LožEK, 1964). The long duration and high temperature of the great interglacial age were also confirmed by paleopedologic investigations in Yugoslavia. The mean thickness of terra rossa in the Riss-Würm interglacial in continental Yugoslavia is about $2 \mathrm{~m}$., but that of the great interglacial age amounts to about $6-7 \mathrm{~m}$. The red colour of the soil belonging to the great interglacial age is much more intense than the colour of the younger terra rossa. Besides this, pedogenetic processes in the Pannonian Basin were interrupted by two colder phases when the loess was accumulated (Marković-MarJanović, 1964). The colour intensity of the "Neufraer Interglazialboden" in southwest Germany indicates a temperature a few degrees higher than now (SCHÄDEL \& WERNER, 1963). The cryoturbation horizon in the Holstein gravel sediments at Edderitz, Germany, is assigned to an influx of cold, and from this possibly follows a bipartition of the great interglacial age into two independent interglacial ages (KNOTH \& LENK, 1962).

If our chronology is correct, Emiliani's stages 11, 12 and 13 may correspond to the great interglacial age. The long duration of this interglacial age in comparison with the 


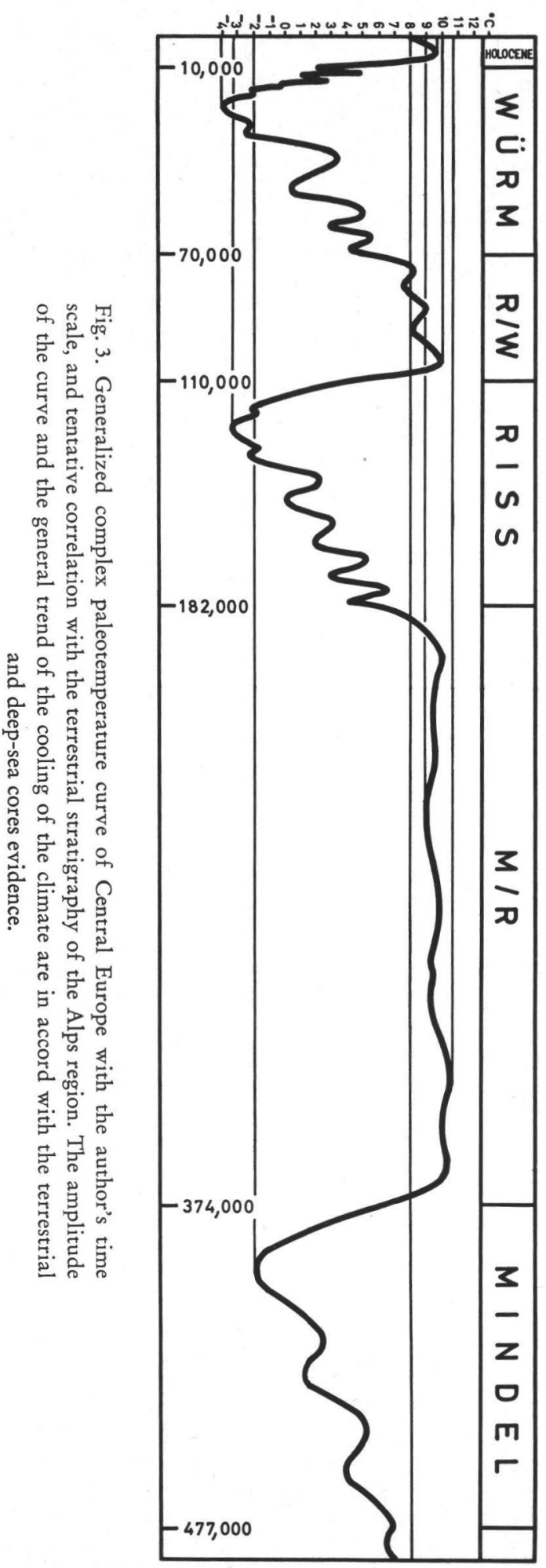


last interglacial age is clearly evident, as in the Pacific Ocean core (ZHuze \& Koreneva, 1959) where the thickness of the sediments belonging to the great interglacial age amounts to $945 \mathrm{~cm}$. in comparison with $460 \mathrm{~cm}$. which is assigned to the last interglacial age. In this section of the EmiLiani curve a little after the middle of the interglacial age one pronounced drop of temperature is cleirly evident, as well as three cool oscillations of much smaller amplitude. This is fairly consistent with the data from the land.

\section{The Temperature of Mindel Glacial}

The deepest section of the core A 172-6 we believe to belong to the Mindel glacial (Emiliani's stage 14). To the same glacial age belong the stages 14,15 and 16 of the core P 6304-9 (EMILIANI, 1966). By means of his generalized temperature curve we reconstructed the paleotemperature of the Mindel glacial. A short analysis of Emiliani's generalized temperature curve reveals that this correlation may be correct. The Mindel section is of the same order of magnitude as the Riss and Würm sections, and consists of three colder stadials separated by two warmer interstadials, exactly by the same mechanism as in all known glacial ages. The areal distribution of the Mindel ice sheets undoubtedly reveals that the temperature drop must have been in essence similar to the temperature drop during the Riss and Würm glacials. The general evolution of the Pleistocene climate leads to the conclusion that the Mindel glacial was a little warmer than the younger glacials, but this is with difficulty discernible. The climatic influence of the Mindel glacial was enormous, causing the extinction of many thermophile forms, but some survived in later interglacial ages and were exterminated by the colder younger glacial ages. In Central Europe this is well decumented by Szafer (1961). The interbedding of loess and fossil soils in Czechoslovakia is attributed to the climatic oscillations within the Mindel glacial (ProšEK \& LožEK, 1957).

\section{Conclusions}

1. Due to the very complex response of organic life to the temperature changes it is not possible to construct the generalized Pleistocene temperature curve solely on the base of the deep-sea cores oxygen isotopic measurements.

2. Interglacial temperature maxima and glacial minima have not reached the same values repeatedly.

3. Throughout the Quaternary Period a slight over-all decrease of the temperature is clearly discernible. This trend continues a trend evident in Pliocene and earlier times.

4. The duration of the glacial and interglacial ages respectively were different and it is not possible to discern any periodicity or temperature cycles.

5. The temperature curves of all glacial ages are in essence similar; maximum drop of the temperature was attained in the later part of their duration. The temperature curves of all glacial ages are asymmetrical.

6. The chronology affirms the theory of a "long Pleistocene", thus avoiding Emiliani's gap between Günz glacial and the very old K-Ar dates for Villafranchian time.

\section{References cited}

Bertsch, K.: Die diluviale Flora des Cannstätter Sauerwasserkalks. Z. Botanik, 19, 641-659, 1927. Black, R. F.: Periglacial phenomena of Wisconsin, north-central United States. VIth Int. Congress INQUA Warszawa 1961, 4, 21-28, Lodz 1964.

Brandtner, F.: Lößstratigraphie und paläolithische Kulturabfolge in Niederösterreich und in den angrenzenden Gebieten. Eiszeitalt. u. Gegenw., 7, 127-175, 1956.

Brelie, G. vON DER: Die pollenstratigraphische Gliederung des Pleistozäns in Nordwestdeutschland. 2. Eiszeitalt. u. Gegenw., 6, 25-38, 1955. 
Broecker, W. S., Turekian, K. K. \& Heezen, B. C.: The relation of deep-sea sedimentation rates to variations in climate. Am. Journ. Sci., 256, 503-517, 1958.

BüDEL, J.: Die Gliederung der Würmkaltzeit. Würzburger geogr. Arb., 8, 44 p., 1960.

CEPEK, A.: Grundmoränenstratigraphie im Quartär Brandenburgs und ihre Bedeutung für das norddeutsche Vereisungsgebiet. Geologie 10, 720-722, 1961.

Charlesworth, J. K.: The Quaternary Era 1, 2. 1700 p., London 1957.

Coope, G. R.: A Pleistocene coleopterous fauna with Arctic affinities from Fladbury, Worcestershire. Quart. J. Geol. Soc., 118, p. 103-117, London 1962. - - Fossil insect faunas from Late Quaternary deposits in Britain. Advanc. Sci., 21, 564-575, 1965.

Coope, G. R,- Shotton, F. W. \& Strachan, I.: A Late Pleistocene fauna and flora from Upton Warren, Worchestershire. Philos. Trans. Roy. Soc. London, B, 244, no. 714, 379-421. 1961.

Deever, E. S. \& Fuint, R. F.: Postglacial Hypsithermal Interval. Science, 125, 182-184. 1957.

Dillon, L. S.: Wisconsin climate and life zones in North America. Science 123, 167-176, 1956.

Dubois, A. \& Stehlin, H. G.: La grotte de Cotencher, station moustérienne. Mém. Soc. paléont. Suisse II, 53, Basle 1933.

Dylik, J.: Sur les changements climatiques pendant la derniere periode froide. VIth Int. Congress INQUA Warszawa 1961, 4, 55-66. Lodz 1964.

Emiliani, C.: Pleistocene temperatures. J. Geol., 63, 538-578, 1955a. - - Pleistocene temperature variations in the Mediterranean. Quarternaria, 2, 87-98, 1955b. - - Note on absolute chronology of human evolution. Science, 123, 924-926, 1956a. - - Paleotemperature analysis of core 280 and Pleistocene correlations. J. Geol., 66, 264-275, 1958. - - Cenozoic climatic changes as indicated by the stratigraphy and chronology of deep-sea cores of Globigerina-ooze facies. N.York Acad. Sci. Ann., 95, 521-536, 1961. - - Paleotemperature analysis of the Caribbean cores A 254-BR-C and CP-28. Geol. Soc. Amer. Bull., 75, 129-144, 1964. - - Paleotemperature analysis of Caribbean cores P6304-8 and P 6304-9 and a generalized temperature curve for the past 425,000 years. J. Geol., 74, 109-126, 1966.

FIRBAS, F.: Uber die späteiszeitliche Verschiebung der Waldgrenze. Naturwissenschaften, 34, 114118, 1947. - - Spät- und nacheiszeitliche Waldgeschichte Mitteleuropas nördlich der Alpen. 1., 480 p., Jena 1949.

FurNt, R. F.: Glacial and Pleistocene geology. N.York, 553 p., 1957. - - Status of the Pleistocene Wisconsin stage in Central North America. Science 139, 402-404, 1963.

Flohn, H.: Studien über die atmosphärische Zirkulation in der letzten Eiszeit. Erdkd., 7, 266-275, 1953.

Florschütz, F.: The subdivisions of the Middle and Young Pleistocene up to the Late-glacial in the Netherlands, England and Germany. Geol. en Mijnb., 19, 245-250, 1957.

GAMs, H.: Neue Beiträge zur Vegetations- und Klimageschichte der nord- und mitteleuropäischen Interglaziale. Experientia, 10, 357-363, 1954.

Gargallo, G.: Reperti malacologici del piano tirreniano nel canale Mussolini. Quaternaria, 5, 241-256, 1962.

Gignoux, M.: Les formations marines pliocènes et quaternaires de l'Italie du Sud et de la Sicile. Ann. Univ. Lyon, 36, 1913.

Gross, H.: Das Mittelwürm in Mitteleuropa und angrenzenden Gebieten. Eiszeitalt. u. Gegenw., 15, 187-198, 1964.

Hafsten, U.: A standard pollen diagram for the Southern High Plains, USA. VIth Int. Congress INQUA Warszawa 1961, 2, 407-420, Lodz 1964.

Haring, A., De Vries, A. E. \& De Vries, H.: Radiocarbon dating up to 70,000 years by isotopic enrichment. Science, 128, 472-473, 1958.

Hough, J.: Pleistocene climatic record in a Pacific Ocean core sample. J. Geol., 61, 252-262, 1953.

Iversen, J.: The late glacial flora of Denmark and its relation to climate and soil. Danm. Geol. Unders. 2, 80, 87-119, 1954.

Jaranoff, D.: Das Klima des Mittelmeergebietes während des Pliozäns und des Quartärs. Geol. Rdsch., 34, 434-446, 1944.

Jessen, K. \& Mrtthers, V.: Stratigraphical and palaeontological studies of the interglacial freshwater deposits in Jutland and northwest Germany. Danm. geol. Unders. 2, 48, 379 p., 1928.

KaIser, K.: Klimazeugen des periglazialen Dauerfrostbodens in Mittel- und Westeuropa. Eiszeitalt. u. Gegenw., 11, 121-141, 1960.

Kerney, M. P., Brown, E. H. \& Chandler, T. J.: The Late-glacial and Post-glacial history of the chalk escarpment near Brook, Kent. Philos. Trans. Roy. Soc. London, B, 248, no. 745, 135-204, 1964.

Kopp, K.-O.: Schneegrenze und Klima der Würmeiszeit der baskischen Küste. Eiszeitalt. u. Gegenw., 14, 188-207, 1963. 
Knoth, W. \& Lenk, G.: Das Pleistozänprofil des ehemaligen Tagebaues Edderitz im Kreis Köthen. Geologie, 11, 1149-1163, 1962.

KretzoI, M.: Stratigraphie und Chronologie. VIth Int. Congress INQUA Warszawa 1961, 1, 313-332, Warszawa 1961.

Lieberoth, I.: Die Stratigraphie der sächsischen Lösse. Ein Beitrag zur Würmchronologie. VIth Int. Congress INQUA Warszawa 1961, 4, 491-501, Lodz 1964.

LožEK, V.: Survey of the Molluscan fauna of the Quaternary sediments in Czechoslovakia on the basis of recent explorations. Sborn. Ústř. úst. geol., 18, 1-20, 1951. - - Quartärmollusken der Tschechoslowakei. Rozpr. Ústřr. úst. geol., 31, 374 p., Prag 1964.

LožEK, V. \& KUKLA, J.: Outline of the stratigraphy of the Czechoslovak Quaternary. VIth Int. Congress INQUA Warszawa, 1, 155-170, 1961.

MANLEY, G.: The range of variation of the British climate. Geogr. J., 117, 43-68, 1951.

Markov, K. K.: Die Typen der geographischen Regionen der Erde und die wichtigsten Züge ihrer Entwicklung im Quartär. Peterm. geogr. Mitt., 109, 15-17, 1965.

Marković-Marjanović, J.: Le loess en Yougoslavie. VIth Int. Congress INQUA Warszawa 1961, 4, 551-570, Lodz 1964.

Mortensen, H.: Heutiger Firnrückgang und Eiszeitklima. Erdkd., 6, 14"5-160, 1952.

Olausson, E.: Evidence of climatic changes in North Atlantic deep-sea cores, in SEARs, M. (ed.): Progress in oceanography. V. 3, 221-252, Oxford 1965.

Panov, D. G.: Paleotemperature conditions and paleoclimatic regionalization of Europe in the latest glaciation epoch. Izv. Vses. geogr. obsch., 96, 480-487, 1964 (in Russian).

PÉCSI, M.: Die periglazialen Erscheinungen in Ungarn. Peterm. geogr. Mitt., 107, 161-182, 1963.

PelíšeK, J.: The Quaternary of the eastern vicinity of Brno. Anthropoz., 3, 7-28, 1954.

Penck, A. \& Brǘckner, E.: Die Alpen im Eiszeitalter. 1199 p., Leipzig 1909.

Pidoplitshro, I. G.: Brief summary of the study of vertebrates from the Anthropogen (Quaternary) deposits of the Ukrainian SSR. Chetv. period, 13-15, p. 261-267, Kiev 1961 (in Russian with English summary).

De Ploey, J.: Morfologie en Kwartair-Stratigrafie van de Antwerpse Noorderkempen. Acta geogr. Lovaniensia, 1, 130 p., Leuven 1961.

Poser, H.: Auftautiefe und Frostzerrung im Boden Mitteleuropas während der Würm-Eiszeit. Naturwissenschaften, 34, 232-238, 262-267, 1947.

PRošEK, F. \& LožEK, V.: Stratigraphische Übersicht des tschechoslowakischen Quartärs. Eiszeitalt. u. Gegenw., 8, 37-90, 1957.

Rabien, I.: Die Vegetationsentwicklung des Interglazials von Wallensen in der Hilsmulde. Eiszeitalt. u. Gegenw., 3, 1953.

Richmond, G. M.: Method for computing departures from present mean annual free-air temperature during Quaternary glacial and soil-forming maxima in the Rocky Mountains region. Abstr. Geol. Soc. Amer. Bull., 64, 1465-1466, 1953.

Rosholt, J. N., Emiliani, C., Getss, J., Koczy, F. F. \& WAngersky, P. J.: Absolute dating of

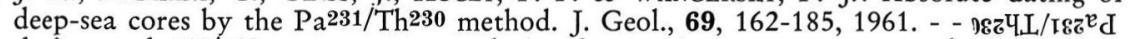
dating and 018/016 temperature analysis of core A254-BR-C. J. Geophys. Res., 67, 2907-2911, 1962.

RÜHLE, E.: Map of Quaternary deposits in Poland. Quatern. Research in Poland, 8, 489-523, 1957.

SCHÄDEL, K. \& WeRnER, J.: Neue Gesichtspunkte zur Stratigraphie des mittleren und älteren Pleistozäns im Rheingletschergebiet. Eiszeitalt. u. Gegenw., 14, 5-26, 1963.

Schulz, W.: Gliederung des Pleistozäns in der Umgebung von Halle. Geologie, Beih., 36, 69 p., 1962.

Schwarzbach, M.: Das Klima der Vorzeit. 2. Aufl., 275 p., Stuttgart 1961.

Shotton, F. W.: The physical background of Britain in the Pleistocene. Advanc. Sci., 19, 193-206, 1962.

Sobolewska, M.: Vitis silvestris Gmel. in the Polish Pleistocene. Quatern. Research in Poland, 5, 159-164, 1954.

Środoń, A.: Pleistocene floras from Tarzymiechy on the river Wieprz. Quatern. Reserarch in Poland, 5, 5-55, 1954.

StraAten, L. van: Composition of shell beds formed in tidal flat environment in the Netherlands and in the Bay of Arcachon. Geol. en Mijnb., 18, 209-226, 1956.

Suess, H. E.: Absolute chronology of the Last Glaciation. Science, 123, 355-357, 1956.

Szafer, W.: Miocene flora from Stare Gliwice im Silesia. Inst. Geol., Prace, 33, $20^{\circ 5}$ p., 1961.

ŠEGTA, T.: Absolute chronology of the Quaternary Period. Bull. Sci., Conseil Acad. R.P.F. Yougoslavie, 6, 39-40, 1961. - - Geographical background to ice ages. Radovi Geogr. inst. Zagreb, 4, 119 p., 1963. - - Quaternary temperature changes in Central Europe. Erdk., 20, 110-118, 1966. 
Terasmae, J.: Notes on Late-Quaternary climatic changes. N.York Acad. Sci. Ann., 95, 658-675, 1961.

UllRich, H.: Fossile Sumpfschildkröten (Emys orbicularis L.) aus dem Diluvialtravertin von Weimar-Ehringsdorf-Taubach und Tonna (Thür.). Geologie, 5, 360, 1956.

VALOCH, K.: Lösse und paläolithische Kulturen in der Tschechoslowakei. Quartär, 10/11, 115-149, 1959.

Vent, W.: Die Pflanzenwelt der Ilmtravertine von Weimar-Ehringsdorf zur Unstrutwarmzeit. Alt-Thüringen, 3, 15-28, 1958.

WasyLikowa, K.: Pollen analysis of the Late-glacial sediments in Witów near Leczyca, Middle Poland. VIth Int. Congress INQUA Warszawa 1961, 2, 497-502, Lodz 1964.

W $_{\text {ATt }}$ A. K.: Correlation of the Pleistocene geology as seen in the subway with that of the Toronto region, Canada. Geol. Assoc. Canada Proc., 6, 69-81, 1954.

Watts, W. A.: Interglacial deposits at Kilbeg and Newtown, Co. Waterford. Proc. Roy. Irish Acad., B 2, 60, 79-134, 1959.

Weischet, W.: Die gegenwärtige Kenntnis vom Klima in Mitteleuropa beim Maximum der letzten Vereisung. Mitt. geogr. Ges. München, 39, 1954.

Werth, E.: Die pflanzenführenden Diluvial-Ablagerungen der thüringisch-sächsischen Bucht und ihre pflanzengeschichtliche und klimatologische Bedeutung. Ber. Dtsch. Bot. Ges., 43, 391-399, 1925.

Williams, R.B.G.: Permafrost in England during the Last Glacial Period. Nature, 205, 1304-1305, 1965.

Woldstedt, P.: Das Eiszeitalter. 1, 374 p., Stuttgart 1954. - - Eine neue Kurve der Würm-Eiszeit. Eiszeitalt. u. Gegenw., 9, 151-154, 1958a. - - Das Eiszeitalter. 2, 438 p., Stuttgart 1958t - - Uber die Gliederung des Quartärs und Pleistozäns. Eiszeitalt. u. Gegenw., 13 $115-124,1962$.

Záruba, Q., KuKLA, J. \& LožeK, V.: Die altpleistozänen Ablagerungen in Žalov bei Prag. Anthropoz. 10, 135-162, 1962.

Zeuner, F. E.: Riss or Wurm? Eiszeitalt. u. Gegenw., 4-5, 98-104, 1954. - - The Pleistocene Period. 447 p., 1959.

Zhuze, A. P. \& Koreneva, E. A.: On the paleogeography of the Okhotsk Sea. Izv. Akad. nauk SSSR, ser. geogr., 2, 12-24, 1959 (in Russian).

Manuskr. eingeg. 5. 3. 1967.

Anschr. d. Verf.: Docent Dr. Tomislav Šegota, Geogr. Inst., Marulićev trg 19, Zagreb (Jugoslavija). 